International Journal of Industrial Engineering Research and Development (IJIERD)

Volume 6, Issue 2, July-Dec 2015, pp. 01-11, Article ID: IJIERD_06_02_001

Available online at https://iaeme.com/Home/issue/IJIERD?Volume $=6 \&$ Issue $=2$

ISSN Print: 0976 - 6979 and ISSN Online: 0976 - 6987

DOI: https://doi.org/10.34218/IJIERD.6.2.2015.001

(C) IAEME Publication

\title{
STUDY ON THE SERVICES OFFERED BY NON VESSEL OPERATING COMMON CARRIERS (NVOCC) IN CHENNAI
}

\author{
Dr. J. Rengamani \\ Associate Professor, AMET Business School, AMET University, India \\ V. Venkatraman \\ Research Scholar, AMET University, India
}

\begin{abstract}
Shipping is the lynchpin of the Indian economy. Without shipping, container trade, the bulk transport of raw materials, and the import/export of affordable food and manufactured goods would simply not be possible. Seaborne trade continues to expand, bringing benefits for consumers across the world as well as India through low and decreasing freight costs. Thanks to the growing efficiency of shipping as a mode of transport and increased economic liberalization, the prospects for the Indian industry's further growth continue to be strong. In the current study, the researcher has done a competitor analysis of major shipping lines and their core competencies in the Chennai sector. The shipping lines such as MAERSK and APL are leading in exports \& imports of containerized cargo from Chennai port to various ports of the world. The future growth of major shipping lines has also been predicted by the researcher. The services offered by the shipping lines have been analyzed through their NVOCCs by using survey method. Most of the shipping lines are offering competitive freight rates and less transit time for the export \& import of containerized cargo. There is yet another core competency identified by the NVOCCs with regard to the selection of the shipping line, which is the online/internet services. NVOCCs would like to accomplish their operations/activities at their ease and hence give more importance to Electronic Data Interchange (EDI) based services.
\end{abstract}

Key words: NVOCCs, Liners, Ports, Shipping Services

Cite this Article: Dr. J. Rengamani and V. Venkatraman. Study on The Services offered by Non Vessel Operating Common Carriers (NVOCC) In Chennai, International Journal of Industrial Engineering Research and Development, 6(2), 2015, pp. 01-11.

http:// http://www.iaeme.com/issue.asp?JType=IJIERD\&VType=6\&IType=2 


\section{INTRODUCTION}

India is one of the oldest seafaring nations and historically has had a large and vital shipping industry. Its shipping fleet occupies a place of importance in India's overseas trade and is currently the 14th largest fleet in the world in terms of deadweight tonnage.

India is among the top 20 maritime nations in the world.. The long coastline and the large number of ports have made shipping a crucial activity for the rapidly growing Indian economy. India's greatest strengths as a maritime nation are its ship breaking facilities and the high quality maritime manpower. The Indian Shipping Industry is worth $\$ 5.5$ Billion (Coastal + Overseas) - The fact that $68 \%$ of Indian exports (in value terms) and 90\% (in volume terms) is carried out through shipping bears testimony to the fact that the development of the shipping industry in India is pivotal to the overall growth of the Indian economy.

Shipping is a global industry and its prospects are closely tied to the level of economic activity in the world. A higher level of industrial activity would generally lead to higher demand for industrial raw materials. This in turn would boost imports and exports. The shipping market is cyclical in nature and freight rates generally tend to be highly volatile. Freight rates and earnings of shipping companies are primarily a function of demand and supply in the markets. While demand drivers are a function of trade growth (growth in world trade) and trade patterns, the supply drivers are a function of new ship building orders as well as scrapping of existing tonnage.

\section{GROWTH OF SHIPPING INDUSTRY IN INDIA}

The natural advantage of an extensive coastline of 7,517 kilometers requires India to use sea transport for the bulk of cargo transport. Following the policy of liberalization, the Indian shipping industry and major ports have been thrown open to the private sector. Shipping activity is buoyant and the number of ships registered under the Indian flag has reached 480. The average age of the shipping fleet in India is 13 years, compared to 17 years of the international shipping fleet. India is also among the few countries that offer fair and free competition to all shipping companies for obtaining cargo. There is no cargo reservation policy in India. However, the shipping industry doesn't move faster. The Indian shipping industry needs to ensure a level playing field. The biggest challenge in the future will not be the quality of ships, but the sea-farers who are moving to tax-free havens.

\section{GOVERNMENT EFFORTS}

Shipping in India is not growing as fast as shipping in other countries due to nonconducive fiscal and regulatory policies, says Kiran Dhingra, Director General of Shipping. "The efforts of the shipping industry would lead to changes in policies, which will let it grow bigger and faster. The government would adopt a positive attitude towards the Indian shipping industry because of the economic growth that has taken place due to its greater efficiency in operations," she said.

The Industry body CII has called for evolving a new mechanism for reviving India's maritime sector to increase private sector investments and enable more efficient management. Development of core infrastructure, port sector in particular, is crucial for the sector to become globally competitive, CII said in a release. The chamber said that with the increase in the number of ships at the Indian ports, providing facilities like ship repair would not only strengthen the sector but also result in generating job opportunities for the local population. The chamber said that though 
Indian ports have a price advantage over other international ports, there is a need to develop conducive policies to provide growth opportunities to private players so that they are at par with the international players.

The Planning Commission of India also agrees that the shipping industry was performing below its potential as the government failed to respond to the changing market scenario and suggested that the problems impeding the sector's growth needed due attention. The need for increased government support - particularly in regard to the various taxes imposed on the shipping industry, has been noted by analysts too.

The core competencies of Shipping Lines are adjudged based on the following factors through NVOCCs.

1. Length of service in the shipping business

2. Frequency of visits by the sales personnel from the shipping line

3. Time taken to provide the Freight Rates

4. Services offered by the Shipping Lines

- Availability of Telephone numbers \& concerned person at the time of need

- Courtesy extended by the line at the time of attending to your calls

- Prompt response at the time of attending to your queries

- Visits/Calls made by Liner Company's Sales representative.

- Filling of EGM \& IGM

- Timely Feedback about Vessel Schedules, Vessel Cut off time, Providing Freight quotation, Arrival notices, Providing EGM \& IGM nos at the time of need, Providing THC, Detention \& other related charges at the time of need

- Timely and Prompt issue of Delivery and Carting order

- Availability of Containers at container yard such as Timely availability of empty container and Condition of containers

- Stuffing/Movement operation at CFS \& Nominated Yard: Availability of space at stuffing shed, Timely movement of containers to CFS/Nominated yard and Services provided at CFS/Nominated yard

- After Sales Service offered by Sales/Customer service department such as Shipped on board details and Transhipment details

- After Sales Service offered by Documentation department such as Courtesy extended at B/L counter, Promptness in issuance of B/L and Error free documentation

- Container Tracking

- Online services/Internet based services provided by the liner

- Receiving Brokerage/Refund Cheques (if any)

\section{INEVITABILITY OF NVOCCS}

An NVOCC is an agent for the exporter in moving cargo to an overseas destination. These agents are familiar with the import rules and regulations of foreign countries, the export regulations of the home country, the methods of shipping, and the documents related to foreign trade. NVOCCs are licensed by the International Air Transport Association (IATA) to handle airfreight and the Federal Maritime Commission to handle ocean freight.

NVOCCs assist exporters in preparing price quotations by advising on freight costs, port charges, consular fees, costs of special documentation, insurance costs, and their handling fees. They recommend the packing methods that will protect the 
merchandise during transit or can arrange to have the merchandise packed at the port or containerized. If the exporter prefers, NVOCCs can reserve the necessary space on a vessel, aircraft, train, or truck. The cost for their services is a legitimate export cost that should be included in the price charged to the customer.

Once the order is ready for shipment, NVOCCs should be reviewing all documents to ensure that everything is in order. This is of particular importance with letter of credit payment terms. They may also prepare the bill of lading and any special required documentation. After shipment, they can route the documents to the seller, the buyer, or to a paying bank. NVOCCs can also make arrangements with customs brokers overseas to ensure that the goods comply with customs export documentation regulations. A customs broker is an individual or company that is licensed to transact customs business on behalf of others. Customs business is limited to those activities involving transactions related to the entry and admissibility of merchandise; its classification and valuation; the payment of duties, taxes, or other charges assessed or collected; or the refund, rebate, or drawback thereof.

\section{REVIEW OF LITERATURE}

The researcher has thoroughly reviewed the literature with regard to the field of shipping. There are many researchers who have done excellent research work in analyzing the operations of Chennai port, Indian major ports, Indian minor ports, Container types, Benefits of containerization, Container Terminal, Container Freight Stations (CFS), Inland Container Depots (ICD), Liner shipping, Liner Trade, EXIM operations, EXIM documentation, Liner services, B/L research, Letter of Credit (LC), Optimum Freight Rates research, Transit Time computation, Voyage estimation, Demurrage/Despatch computations, General cost analysis such as Terminal Handling Costs, Importance of NVOCCs, Consolidation, FCL/LCL research and Customs House operations.

\section{RESEARCH OBJECTIVES}

- To identify the services offered by the major shipping lines to the NVOCCs in the container trade

- To analyze the core competencies of shipping lines through NVOCCs

\section{METHODOLOGY}

In the current study, the researcher has collected information about the core competencies of 12 major shipping lines from the NVOCCs who are doing business in the Chennai sector. The Primary data are collected from the NVOCCs who are utilizing the services of the major shipping lines in the Chennai sector. The information from the NVOCCs has been collected with the help of a structured questionnaire. Here Samples are collected based on referrals. Initially a few set of samples were selected based on the convenience of the researcher and the sample base were increased by obtaining further reference from the samples. The researcher has selected a sample size of 80 (out of an approximate population of 700 NVOCCs) based on the ad-hoc basis. It means that the researcher has collected information from 80 NVOCCs in Chennai who are doing freight forwarding business with 12 major shipping lines. 


\section{QUESTIONNAIRE ANALYSIS}

Table 1 Length of Service in the Freight Forwarding Business

\begin{tabular}{|c|c|c|}
\hline Age & Response & Percentage \\
\hline$<2$ & 5 & 6.25 \\
\hline $2-5$ & 9 & 11.25 \\
\hline $5-10$ & 28 & 35.00 \\
\hline $10-15$ & 21 & 26.25 \\
\hline$>15$ & 17 & 21.25 \\
\hline TOTAL & 80 & 100.00 \\
\hline
\end{tabular}

Inference: From TABLE-1, it can be inferred that out of 80 respondents, 35\% of the respondents are doing the freight forwarding business for 5-10 years. This is followed by year groups $10-15$ and $>15$ with $26 \% \& 21 \%$ respectively.

Table-2 Shipping Line Used For Exports \& Imports

\begin{tabular}{|l|c|c|}
\hline Liner & Response & Percentage \\
\hline APL & 9 & 11.25 \\
\hline CMA & 10 & 12.5 \\
\hline HANJIN & 4 & 5 \\
\hline HL & 5 & 6.25 \\
\hline HMM & 2 & 2.5 \\
\hline KLINE & 4 & 5 \\
\hline MAERSK & 17 & 21.25 \\
\hline NYK & 8 & 10 \\
\hline PIL & 4 & 5 \\
\hline PONL & 12 & 15 \\
\hline RCL & 3 & 3.75 \\
\hline SCI & 2 & 2.5 \\
\hline TOTAL & 80 & 100 \\
\hline
\end{tabular}

Inference: From TABLE 2, it can be understood that out of 80 respondents, $21 \%$ of the respondents are utilizing the services offered by MAERSK line and this is followed by PONL, CMA, APL and NYK with $15 \%, 13 \%, 11 \%$ \& $10 \%$ respectively.

Table 3 Frequency of Sales Personnel Visit

\begin{tabular}{|l|c|c|}
\hline Visit & Response & Percentage \\
\hline Weekly & 18 & 22.5 \\
\hline Fortnightly & 16 & 20 \\
\hline Monthly & 5 & 6.25 \\
\hline On request & 41 & 51.25 \\
\hline Never & 0 & 0 \\
\hline & 80 & 100 \\
\hline
\end{tabular}

Inference: From TABLE 3, it can be inferred that out of 80 respondents, $51 \%$ of the respondents have specified that the frequency of Sales personnel visit to their company is based "on request". 
Study on The Services offered by Non Vessel Operating Common Carriers (NVOCC) In Chennai

Table 4 Time Taken To Provide the Freight Rates

\begin{tabular}{|l|c|c|}
\hline Time taken & Response & Percentage \\
\hline Instantly & 18 & 22.5 \\
\hline Few hours & 2 & 2.5 \\
\hline One day & 5 & 6.25 \\
\hline More time & 17 & 21.25 \\
\hline Depends & 38 & 47.5 \\
\hline TOTAL & 80 & 100 \\
\hline
\end{tabular}

Inference: From TABLE 4, it can be inferred that out of 80 respondents, $48 \%$ of the respondents have specified that the time taken by the shipping line to provide the Freight Rates "Depends" on various factors that are normally considered.

Table 5 Opinion on the Freight Rates

\begin{tabular}{|l|c|c|}
\hline Opinion on Freight Rates & Response & Percentage \\
\hline Expensive & 5 & 6.25 \\
\hline Competitve & 36 & 45 \\
\hline Nominal & 11 & 13.75 \\
\hline Attractive & 7 & 8.75 \\
\hline Relatively Cheaper & 21 & 26.25 \\
\hline TOTAL & 80 & 100 \\
\hline
\end{tabular}

Inference: From TABLE 5, it can be inferred that out of 80 respondents, $45 \%$ of the respondents have indicated that the Freight rates quoted by the shipping lines are competitive.

Table 6 Importance of Transit Time in Selecting Shipping Line

\begin{tabular}{|l|c|c|}
\hline Transit Time Selection & Response & Percentage \\
\hline Important & 8 & 10 \\
\hline Based on FR & 20 & 25 \\
\hline Urgency & 32 & 40 \\
\hline Cargo & 18 & 22.5 \\
\hline Least important & 2 & 2.5 \\
\hline TOTAL & 80 & 100 \\
\hline
\end{tabular}

Inference: From TABLE 6, it can be inferred that out of 80 respondents, $40 \%$ of the respondents have specified that the consideration of Transit Time depends on the "Urgency" of taking the cargo to its due destination.

Table 7 Satisfaction of Transit Time Provision

\begin{tabular}{|l|c|c|}
\hline Transit Time Satisfaction & Response & Percentage \\
\hline Very much satisfied & 10 & 12.5 \\
\hline Satisfied & 46 & 57.5 \\
\hline OK & 22 & 27.5 \\
\hline Dissatisfied & 2 & 2.5 \\
\hline Very much dissatisfied & 0 & 0 \\
\hline TOTAL & 80 & 100 \\
\hline
\end{tabular}

Inference: From TABLE 7, it can be inferred that out of 80 respondents, $58 \%$ of the respondents are satisfied with the Transit Time provided by their shipping lines. 
Dr. J. Rengamani and V. Venkatraman

Table 8 (I) Services Offered By Shipping Lines

\begin{tabular}{|c|c|c|c|c|c|c|}
\hline SERVICES OFFERED & Poor & $\begin{array}{c}\text { Below } \\
\text { Average }\end{array}$ & $\begin{array}{c}\text { Satis } \\
\text { factory }\end{array}$ & Good & Excellent & $\begin{array}{c}\text { Weighted } \\
\text { Average }\end{array}$ \\
\hline Availability of persons on need & 0 & 0 & 26 & 41 & 13 & 20.47 \\
\hline Courtesy extended by the line & 0 & 0 & 17 & 55 & 8 & 20.73 \\
\hline Prompt Response to queries & 0 & 1 & 11 & 54 & 14 & 21.40 \\
\hline Visits-Calls made by liner sales rep & 0 & 1 & 19 & 49 & 11 & 20.67 \\
\hline Filling of EGM \& IGM & 0 & 0 & 21 & 43 & 16 & 21.00 \\
\hline Vessel Schedules & 0 & 0 & 2 & 14 & 64 & 25.47 \\
\hline Vessel Cut off time & 0 & 0 & 1 & 11 & 68 & 25.80 \\
\hline Providing Freight quotation & 0 & 0 & 0 & 7 & 73 & 26.20 \\
\hline Arrival notices & 0 & 0 & 1 & 11 & 68 & 25.80 \\
\hline Providing EGM \& IGM & 0 & 0 & 0 & 9 & 71 & 26.07 \\
\hline Providing THC, Detention & 0 & 0 & 4 & 6 & 70 & 25.73 \\
\hline Timely and Prompt issue of DO & 0 & 0 & 3 & 4 & 73 & 26.00 \\
\hline Availability of empty container & 0 & 2 & 21 & 38 & 19 & 20.93 \\
\hline Condition of containers & 0 & 5 & 26 & 35 & 14 & 19.87 \\
\hline Space at stuffing shed & 0 & 1 & 11 & 51 & 17 & 21.60 \\
\hline Timely movement & 0 & 0 & 8 & 61 & 11 & 21.53 \\
\hline Services provided & 0 & 2 & 6 & 59 & 13 & 21.53 \\
\hline Shipped on board details & 0 & 0 & 4 & 11 & 65 & 25.40 \\
\hline Transhipment details & 0 & 0 & 2 & 17 & 61 & 25.27 \\
\hline $\mathrm{B} / \mathrm{L}$ counter & 0 & 0 & 8 & 38 & 34 & 23.07 \\
\hline Issuance of B/L & 0 & 0 & 7 & 25 & 48 & 24.07 \\
\hline Error free documentation & 0 & 0 & 1 & 24 & 55 & 24.93 \\
\hline Container Tracking & 0 & 0 & 4 & 9 & 67 & 25.53 \\
\hline Online services/Internet & 0 & 0 & 1 & 4 & 75 & 26.27 \\
\hline Receiving Brokerage & 0 & 0 & 19 & 49 & 12 & 20.87 \\
\hline
\end{tabular}


Study on The Services offered by Non Vessel Operating Common Carriers (NVOCC) In Chennai

Table 8(II) Services Offered By Shipping Lines-Consolidated

\begin{tabular}{|l|l|}
\hline SERVICES OFFERED & $\begin{array}{l}\text { Consolidated } \\
\text { Weighted Average }\end{array}$ \\
\hline (a) Availability of persons on need & 20.47 \\
\hline (b) Courtesy extended by the line & 20.73 \\
\hline (c) Prompt Response to queries & 21.40 \\
\hline (d) Visits-Calls made by liner sales rep & 20.67 \\
\hline (e) Filling of EGM \& IGM & 21.00 \\
\hline (f) Timely Feedback & 25.84 \\
\hline g) Timely and Prompt issue of DO & 26.00 \\
\hline (h) Availability of Containers at yard & 20.40 \\
\hline (i) Stuffing/Movement operation at CFS & 21.56 \\
\hline (j) Sales/Customer service department & 25.33 \\
\hline (k) Documentation department & 24.02 \\
\hline (l) Container Tracking & 25.53 \\
\hline (m) Online services/Internet & 26.27 \\
\hline (n) Receiving Brokerage & 20.87 \\
\hline
\end{tabular}

\section{GRAPH 1: SERVICES OFFERED BY SHIPPING LINES-CONSOLIDATED}

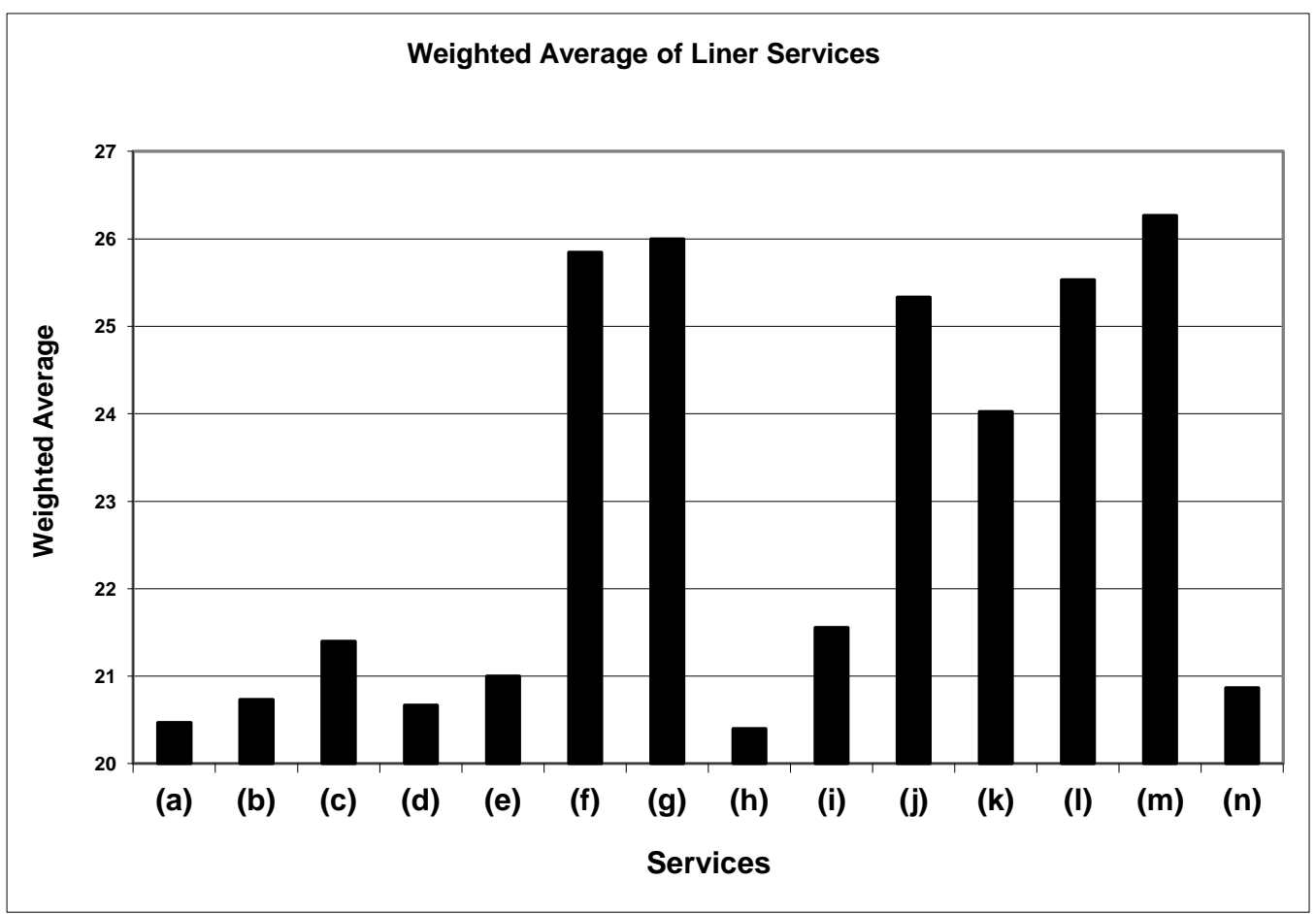

Inference: From TABLE 8 (i), TABLE 8 (ii) \& GRAPH-1, it can be inferred that the weighted average of "Online services/Internet -26.27 " is higher than the weighted averages of all other services offered by the shipping lines. This means that the NVOCCs expectations are more towards the provision of Online services of various shipping lines. The NVOCCs would like to complete their operations at a faster pace and also with higher accuracy. To satisfy their requirements, each and every shipping line has come out with an array of online/internet services. Using these online services, it would be possible for the NVOCCs to accomplish their tasks at great ease. This might be the reason for the selection of this service by the NVOCCs.

This is followed by the services such as Timely and Prompt issue of Delivery Order by the shipping line, Timely Feedback of operational details (such as Vessel 
arrival, Vessel schedules, provision of EGM/IGM, etc), Container Tracking \& Services offered by the Sales/Customer service department of shipping line with weighted averages of $26.00,25.84,25.53 \& 25.33$ respectively.

It is very much evident that the NVOCCs expectations with their shipping lines are oriented more towards the provision of information on-time. The reason may be due to the urgency of taking the containerized cargo to their due destinations at the quickest possible time with less money spent on the freight rates. Moreover these people bother more about the whereabouts of the containerized cargo while they are in transit.

Table 9 Core Competencies of Shipping Lines

\begin{tabular}{|l|c|c|c|c|c|c|}
\hline LINER & $\begin{array}{c}\text { Availability of } \\
\text { Container }\end{array}$ & $\begin{array}{c}\text { Container } \\
\text { Tracking }\end{array}$ & $\begin{array}{c}\text { Online } \\
\text { Services }\end{array}$ & $\begin{array}{c}\text { Freight } \\
\text { Rates }\end{array}$ & $\begin{array}{c}\text { Transit } \\
\text { Time }\end{array}$ & Total \\
\hline APL & 1 & & & 5 & 3 & 9 \\
\hline CMA & & & & 6 & 4 & 10 \\
\hline HANJIN & & & & 4 & & 4 \\
\hline HL & 1 & 1 & & 2 & 1 & 5 \\
\hline HMM & & & & 1 & 1 & 2 \\
\hline KLINE & 1 & & & 2 & 1 & 4 \\
\hline MAERSK & 3 & 1 & 2 & 6 & 5 & 17 \\
\hline NYK & & 1 & 2 & 3 & 2 & 8 \\
\hline PIL & & & & 2 & 2 & 4 \\
\hline PONL & & & & 7 & 5 & 12 \\
\hline RCL & & & & 1 & 2 & 3 \\
\hline SCI & & & & 2 & & 2 \\
\hline Total & 6 & 3 & 4 & 41 & 26 & 80 \\
\hline
\end{tabular}

GRAPH 2 CORE COMPETENCIES OF SHIPPING LINES

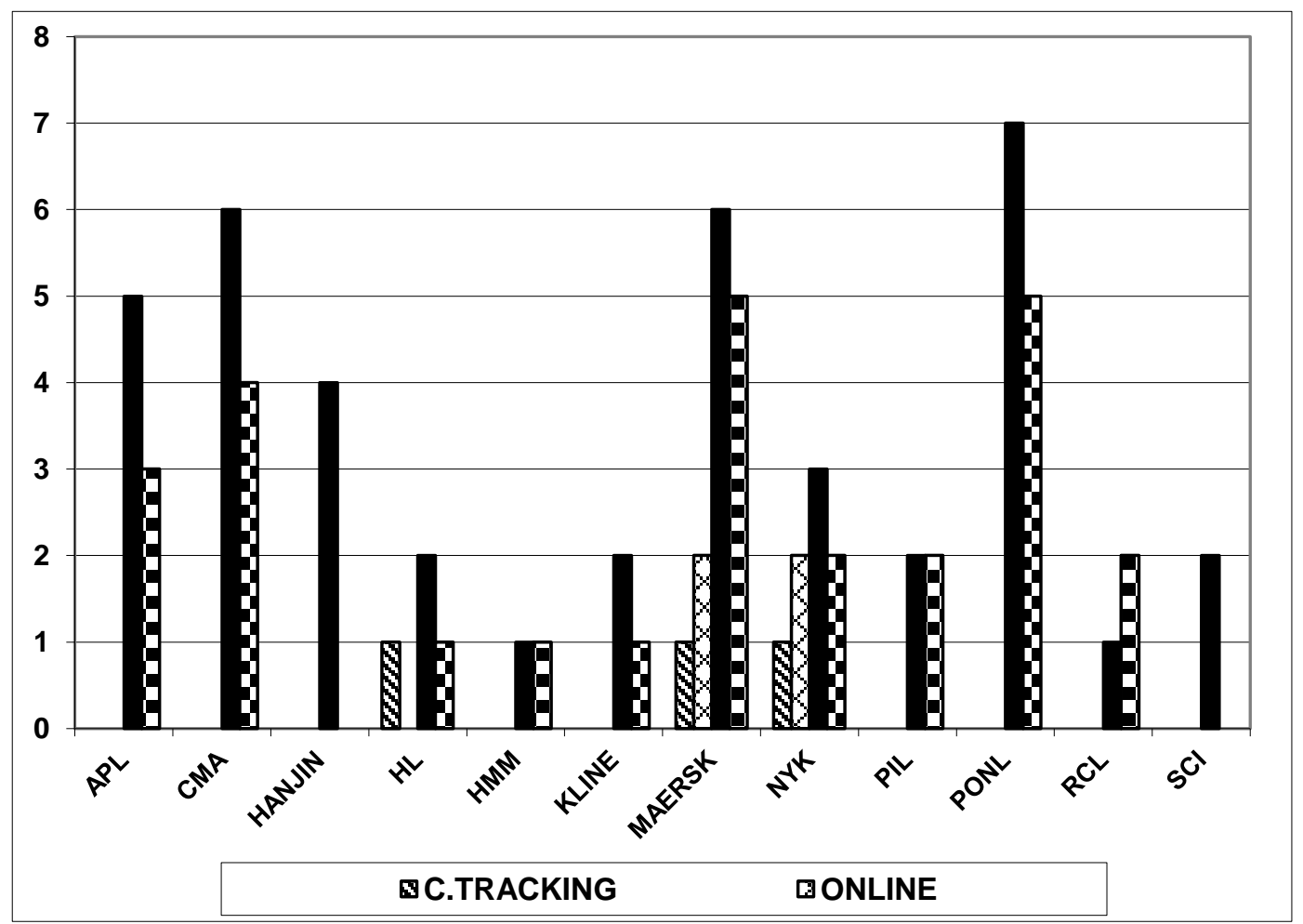


Inference: From TABLE 9 \& GRAPH 2, it can be inferred that the core competencies of all the shipping lines are Freight Rates quoted and the Transit Time offered by them. This essentially means that the NVOCCs expect a sort of competitive freight rates and lesser Transit Time in taking the containerized cargo in both exports \& imports. And it is very much evident that most of the NVOCCs have chosen these two options with regard to the core competencies of shipping lines. The NVOCCs would never mind in switching to the rival shipping line if the rival is going to offer better freight rates and lesser transit time. Hence these two options are considered to be the most sought-after Core Competencies in the selection of the shipping line.

Table 10 Overall Performance of The Shipping Line

\begin{tabular}{|l|c|c|c|c|c|c|}
\hline LINE & Poor & Moderate & C.B & Good & Excellent & Total \\
\hline APL & 0 & 0 & 4 & 4 & 1 & 9 \\
\hline CMA & 0 & 2 & 3 & 5 & 0 & 10 \\
\hline HANJIN & 0 & 0 & 1 & 2 & 1 & 4 \\
\hline HL & 0 & 0 & 1 & 2 & 2 & 5 \\
\hline HMM & 0 & 0 & 1 & 1 & 0 & 2 \\
\hline KLINE & 0 & 0 & 0 & 3 & 1 & 4 \\
\hline MAERSK & 0 & 2 & 5 & 6 & 4 & 17 \\
\hline NYK & 0 & 0 & 1 & 5 & 2 & 8 \\
\hline PIL & 0 & 0 & 1 & 3 & 0 & 4 \\
\hline PONL & 0 & 1 & 2 & 5 & 4 & 12 \\
\hline RCL & 0 & 0 & 1 & 2 & 0 & 3 \\
\hline SCI & 0 & 0 & 1 & 1 & 0 & 2 \\
\hline Total & 0 & 5 & 21 & 39 & 15 & 80 \\
\hline
\end{tabular}

Inference: From TABLE 10, it can be inferred that the NVOCCs who are doing business with MAERSK shipping line are very much satisfied with the services offered by them. This essentially means that the services of MAERSK line are excellent. This is followed by PONL, NYK, CMA and APL.

\section{CONCLUSION}

The following are the services that are normally offered by the Shipping Lines to their NVOCCs:

- Availability of Telephone numbers \& concerned person at the time of need

- Courtesy extended by the line at the time of attending to the calls

- Prompt Response to the queries

- Visits-Calls made by liner sales representatives

- Filling of EGM \& IGM

- Timely Feedback on vessel schedules \& other related details

- Timely and Prompt issue of Delivery Order

- Availability of Containers at container yard

- Stuffing/Movement operation at CFS

- Services offered by Sales/Customer service department

- Services offered by Documentation department

- Container Tracking

- Online services/Internet based services

- Receiving Brokerage/Refund Cheques 
The Core competencies of the major shipping lines have been analyzed through their NVOCCs. The core competencies of the shipping lines are Freight Rates, Transit Time, Availability of containers, Online services and Container tracking. The decision to fix up a particular shipping line largely depends on the Freight rates offered by the line. It essentially means that the shipping line which offers lesser freight rates would obviously be selected by the NVOCCs in the container trade. This will force all the shipping lines to set a sort of competitive freight rates to stay alive in the market.

Transit time is also given an equal importance in the selection of a shipping line. Hence the shipping lines have seamlessly increased the transit time to take the containerized cargo from Chennai sector to various destinations of the world.

The containers are made available to the NVOCCs by the shipping line through Container Freight Station (CFS) or Inland Container Depots (ICD). The CFS/ICD service offered by the shipping line will dramatically reduce the burden of loading/unloading of cargo into the containers. Nowadays, this service is given a predominant importance in the selection of the shipping line in the container trade and has ultimately become a core competency.

The online/internet services offered by the shipping line will facilitate the accomplishment of various activities/operations that are connected with the export and import of containerized cargo in the container trade.

The NVOCCs have started giving more importance to the Container tracking facility offered by the shipping line. The container tracking facility will put the NVOCC to know the exact location of the containers which are loaded with the cargo. This facility will be immense use in the process of identifying the whereabouts of the containers and hence this service has also become a core competency in the selection of the shipping line.

\section{REFERENCES}

[1] D.K.Sharma, "The growing ports of India", Lakshmi Publications, New Delhi, 2003

[2] J.M.Ravath, "Golden years of Indian Ports", Sanmar publications, Mumbai, 2002

[3] Dr.K.V.Hariharan, "Containerization and Multimodal Transport in India", 4th Edition, Shroff Publishers \& Distributors Pvt Ltd., Mumbai, 2003

[4] Mark D.Booker, "Containers - Conditions, Law \& Practice", Derek Beattie Publishing, 1997

[5] M.Padmashree, "Tale of Two Ports", Newsun publications, 1999

[6] Philip Kotler, "Principles of Marketing", Prentice-Hall of India, 2002

[7] S.P.Gupta, "Statistical Methods", Sultan \& sons Publishers, 2006

[8] Vijaendra Acharya, "Indian Port Report: 10 years of Reforms and Challenges ahead", MBD publications, New Delhi, 2004

[9] Performance of Major Indian Ports during 1995-96, Ministry of Surface Transport Annual Report.

[10] Dr.Jose Paul, "Containerization in India". Express Exim review, Mumbai, 1997

[11] Eric Rath, "Container Systems", John Wiley \& Sons, New York

[12] A.K.Kohli, "Container Corporation of India", The Link Publishers, 2002 